\title{
MEDIA CCT (CARD OF CRITICAL THINKING) DALAM PEMBELAJARAN MATEMATIKA
}

\author{
Dyani Primaningsih") \\ ${ }^{1)}$ SMAN I Nglames, Jl. Raya Nglames, Kab. Madiun; dyeprime@ gmail.com
}

\begin{abstract}
Abstrak. Keterampilan berfikir yang dapat dikembangkan melalui pendidikan matematika adalah berfikir kritis. Salah satu langkah yang dapat dilakukan guru untuk menstimulus keterampilan berfikir kritis adalah menggunakan media pembelajaran berupa CCT (Card Of Critical Thinking). CCT adalah media pembelajaran yang berbentuk kartu-kartu soal, dan memuat pertanyaan berfikir kritis yaitu "apakah ada yang salah, mengapa salah, dan apa yang harus dilakukan untuk mengoreksi kesalahannya". Pertanyaan- pertanyaan yang terdapat dalam CCT ini memenuhi kriteria dan indikator berfikir kritis yaitu FRISCO (Focus, Reason, Inference, Situation, Clarity, Overview). Penerapan CCT ini dilakukan melalui pendekatan PBL (Problem Based Learning). Tujuan utama dari studi literasi ini adalah untuk mendeskripsikan langkahlangkah pembelajaran melalui penerapan CCT (Card Of Critical Thingking) yang dapat meningkatkan kemampuan berfikir kritis siswa.
\end{abstract}

Kata Kunci. CCT, Media pembelajaran, Berfikir kritis

\section{CCT (Cards Of Critical Thinking) Media In Mathematics Teaching And Learning}

\begin{abstract}
One of the thinking skills can be developed through mathematics education is critical thinking. Teacher may take one of the steps to stimulate critical thinking skills by means of CCT (Cards of Critical Thinking) learning media. CCT is a learning media in the form of question cards; containing critical thinking questions like "is there something wrong, why it is wrong, and what should be done to correct the mistakes". The questions in this CCT met the criteria and indicators of critical thinking, namely FRISCO (Focus, Reason, Inference, Situation, Clarity, and Overview). The CCT is applied through the PBL (Problem Based Learning) approach. The main purpose of this literacy study is to describe teaching and learning steps through the application of CCT (Cards of Critical Thinking) to improve students' critical thinking skills.
\end{abstract}

Keywords: CCT, Learning Media, Creative thinking

\section{Pendahuluan}

Saat ini, Indonesia sudah memasuki era revolusi industri 4.0 atau revolusi industri dunia. Era revolusi industri 4.0, sering juga dinamakan era disrupsi dimana terjadi perubahan besarbesaran pada semua bidang kehidupan sebagai dampak teknologi modern, tak terkecuali perubahan ini terjadi juga pada bidang pendidikan (Brown, 2018, Chao Jr, R., 2017). Salah satu dampak dari era ini adalah banyaknya satuan pendidikan yang telah menerapkan teknologi digital dalam pengajaran, yang mampu menembus tembok ruang kelas, batas-batas sekolah, dan bahkan negara. Semakin terbukanya sistem informasi menuntut siswa untuk mampu menganalisis informasi, dan mengintegrasikan berbagai sumber pengetahuan untuk memecahkan masalah. 
Trilling \& Fadel (2009) menyatakan bahwa keterampilan yang dibutuhkan untuk dapat bertahan di era revolusi industri ini adalah (1) life and career skills, (2) learning and innovation skills, dan (3) Information media and technology skills. Learning and innovation skills (keterampilan belajar dan berinovasi) meliputi (a) berpikir kritis dan mengatasi masalah (Critical Thinking and Problem Solving), (b) komunikasi dan kolaborasi (Communication and Collaboration), (c) kreativitas dan inovasi (Creativity and Innovation). Berdasarkan uraian di atas menunjukkan bahwa salah satu keterampilan yang dibutuhkan peserta didik dalam memilih, dan memilah informasi adalah berpikir kritis.

Berpikir kritis dapat dikembangkan melalui pendidikan matematika (Askury, 2007). Pusat kurikulum (2006) juga menyatakan bahwa pembelajaran matematika bertujuan untuk membekali siswa dengan kemampuan berpikir kritis dan kreatif. Hal ini terjadi karena salah satu aspek yang ditekankan dalam matematika adalah meningkatkan kemampuan penalaran peserta didik. Krulik \& Rudnick (1995) membuat tingkat penalaran yang merupakan bagian dari profil berpikir menjadi tiga tingkatan diatas pengingatan atau recall. Tingkatan itu adalah berpikir dasar (basic), berpikir kritis (critical), dan berpikir kreatif. Dengan kata lain, matematika menekankan kemampuan penalaran yang salah satunya adalah berpikir kritis. Di dalam matematika, kemampuan berpikir kritis ini berguna untuk mengatasi masalah dalam situasi dunia nyata, menghadapi tantangan karier, kewajiban, dan tanggung jawab, menyaring informasi, dan pemecahan masalah matematika (Rosnani \& Suhailah, (2003), Vieira dkk., (2011), Ocak \& Eğmir, (2016), Uzel \& Uyangor, (2006)).

Mengingat pentingnya kemampuan berfikir kritis dalam perkembangan kualitas kehidupan siswa ke depannya, maka seorang guru harus mampu memfasilitasi mereka untuk menjadi pemikir dan pemecah masalah yang baik. Salah satu langkah yang dapat dilakukan guru diantaranya yaitu dengan melaksanakan pembelajaran matematika yang tidak hanya berfokus pada kegiatan transfer ilmu pengetahuan, tetapi mampu menciptakan lingkungan dan pengalaman yang kreatif (to create creative environment and experience) bagi siswa serta dapat membantu mereka dalam menemukan dan membangun pengetahuan tersebut (Huda, 2014). Pembelajaran matematika yang dimaksud adalah dengan memanfaatkan suatu masalah non rutin yang tidak dapat dipecahkan dengan prosedur baku serta belum pernah dihadapi siswa sebelumnya. Dengan kata lain, soal yang diberikan adalah soal yang memiliki struktur yang berbeda dengan soal yang pernah dicontohkan guru, sehingga soal tersebut benar-benar baru bagi siswa. Melalui pemberian soal seperti ini, siswa dituntut untuk mampu menafsirkan solusi dari soal tersebut. Menafsirkan solusi mengandung arti bahwa siswa tidak berhenti menelaah soal hanya karena jawaban terhadap soal telah ditemukan. Akan tetapi kegiatan penafsiran ini selain tidak begitu jelas, juga tidak cukup membuat siswa menggunakan keterampilan berpikir tingkat tingginya.

Menurut Krulik \& Rudnick (1995) salah satu masalah yang dapat digunakan untuk melatih kemampuan berpikir kritis adalah dengan memberikan pertanyaan-pertanyaan Apakah jika?, Apakah ada yang salah?. Selain pelaksanaan pembelajaran matematika yang memungkinkan siswa melatih kemampuan berfikir, maka juga harus memperhatikan cara mengajar yang menyenangkan sehingga menarik perhatian, dan motivasi belajar siswa. Salah satu cara yang dapat digunakan untuk menarik perhatian, dan motivasi belajar siswa adalah melalui penggunaan media pembelajaran. 
Media pembelajaran yang dapat menstimulus kemampuan berfikir kritis, sekaligus meningkatkan minat atau perhatian siswa adalah CCT (Card Of Critical Thinking). CCT ini adalah media pembelajaran yang berbentuk kartu-kartu soal, dan memuat pertanyaan berfikir kritis yaitu "apakah ada yang salah, mengapa salah, dan apa yang harus dilakukan untuk mengoreksi kesalahannya". Pertanyaan- pertanyaan yang terdapat dalam CCT ini memenuhi kriteria dan indikator berfikir kritis yaitu FRISCO (Focus, Reason, Inference, Situation, Clarity, Overview). Penerapan CCT ini dilakukan melalui pendekatan PBL (Problem Based Learning). Pendekatan PBL dipilih karena pada media CCT karena lebih menekankan pada penyelesaian soal-soal berfikir kritis,sehingga sesuai dengan sintaks pendekatan PBL. Selain itu, melalui PBL diharapkan siswa dapat membangun pengetahuan sendiri sehingga pembelajaran yang dilakukan menjadi lebih bermakna. Hasil penelitian dari Masek \& Yamin (2011), Roh (2003), Widyatiningtyas dkk. (2015), dan Salim (2016) menyatakan bahwa PBL dapat mengembangkan kemampuan berfikir kritis siswa

Media CCT ini memberikan kesempatan pada setiap anggota kelompok belajar untuk dapat berperan aktif dalam menyampaikan pendapat agar dapat menyelesaikan masalah yang diberikan. Melalui CCT ini diharapkan siswa dapat meningkatkan kemampuan berfikir kritis terutama di bidang matematis. Hal ini terjadi karena siswa dilatih untuk menyelesaikan atau menghadapi soal-soal yang memuat indikator berfikir kritis. Semakin sering siswa menyelesaikan soal-soal berfikir kritis maka diharapkan kemampuan berfikir tingkat tingginya semakin meningkat. Berdasarkan uraian di atas maka tujuan utama dari studi literasi ini adalah mendeskripsikan langkah-langkah pembelajaran menggunkan media CCT (Card Of Critical Thingking) untuk dapat meningkatkan kemampuan berfikir kritis siswa.

\section{Media Card Of Critical Thingking Berdasarkan Kriteria Berfikir Kritis}

Scriven, \& Paul (1987) mendeskripsikan berpikir kritis sebagai proses intelektual yang penuh dengan pemahaman konseptual dalam menerapkan, menganalisis, mensintesis, dan atau mengevaluasi informasi yang telah dikumpulkan, atau dihasilkan dari mengobservasi, pengalaman, refleksi, atau berkomunikasi sebagai dasar untuk melakukan tindakan. Huitt, (1998) mendefinisikan berpikir kritis sebagai aktivitas disiplin mental dalam mengevaluasi pendapat atau masalah dan membuat keputusan yang dapat diyakini kebenarannya dan digunakan sebagai dasar melakukan suatu tindakan. Berdasarkan pendapat di atas dapat disimpulkan bahwa berpikir kritis adalah suatu proses pengambilan keputusan berdasarkan informasi yang ada.

Di dalam proses pembelajaran matematika, kemampuan berfikir krtitis siswa dapat distimulus dengan berbagai macam cara. Salah satu cara yang dapat dilakukan guru adalah memfasilitasi siswa dengan media pembelajaran yang dapat menstimulus kemampuan berfikir. CCT (Card Of Critical Thingking) adalah sebuah media pembelajaran berbentuk kartu-kartu soal yang dikembangkan untuk menstimulus kemampuan berfikir kritis siswa. Soal-soal yang terdapat di dalam CCT adalah permasalahan yang memuat indikator berfikir kritis. Menurut Ennis, (2011) seseorang dikatakan berfikir krtitis jika memenuhi enam kriteria berpikir kritis yang disingkat dengan FRISCO (Focus, Reason, Inference, Situation, Clarity, Overview) yaitu :

F (Focus): Untuk membuat sebuah keputusan tentang apa yang diyakini maka harus bisa 
memperjelas pertanyaan atau isu yang tersedia, yang coba diputuskan itu mengenai apa.

$\mathrm{R}$ (Reason): Mengetahui alasan-alasan yang mendukung atau melawan putusan-putusan yang dibuat berdasar situasi dan fakta yang relevan. Alasan itu dapat berasal dari informasi yang diketahui ataupun teorema, sifat, dan lain-lain. Alasan merupakan dasar bagi suatu proses penarikan kesimpulan.

I (Inference): Penarikan kesimpulan yang benar harus didasarkan pada langkah-langkah dari alasan-alasan ke kesimpulan yaitu masuk akal atau logis. Bagian penting dari langkah penyimpulan ini adalah mengidentifikasi asumsi dan mencari pemecahan, pertimbangan dari interpretasi akan situasi dan bukti.

S (Situation): Memahami situasi dan selalu menjaga situasi dalam berpikir akan membantu memperjelas pertanyaan (dalam F), dan mengetahui arti istilah-istilah kunci, bagian-bagian yang relevan sebagai pendukung.

C (Clarity): Menjelaskan arti atau istilah-istilah yang digunakan dalam berpendapat baik secara lisan maupun tulisan. Kejelasan mengarah pada menggambarkan perbedaan makna untuk menghindari kebingungan.

O (Overview): Meninjau kembali dan meneliti secara menyeluruh keputusan yang diambil.

Berdasarkan kriteria di atas maka dapat ditentukan indikator berpikir kritis yang disajikan dalam Tabel 1. berikut.

Tabel 1. Kriteria dan Indikator Berpikir Kritis

\begin{tabular}{|c|l|l|}
\hline No & \multicolumn{1}{|c|}{ Kriteria Berpikir Kritis } & \multicolumn{1}{|c|}{ Indikator } \\
\hline 1 & Focus (Fokus) & $\begin{array}{l}\text { Mengidentifikasi masalah } \\
-\end{array}$ \\
\hline 2 & Remeriksa data yang ada \\
\hline 3 & Inference (Kesimpulan) & $\begin{array}{l}\text { Memberikan alasan berdasarkan fakta dan } \\
\text { situasi yang relevan }\end{array}$ \\
\hline 4 & Situation (Situasi) & $\begin{array}{l}\text { Membuat kesimpulan berdasarkan fakta } \\
\text { yang ada }\end{array}$ \\
\hline 5 & Clarity (Kejelasan) & Memahami konteks permasalahan \\
\hline 6 & Overview (Meninjau Kembali) & $\begin{array}{l}\text { Menjelaskan arti atau istilah-istilah yang } \\
\text { digunakan dalam berpendapat baik secara } \\
\text { lisan maupun tulisan. }\end{array}$ \\
\hline
\end{tabular}

Seseorang yang berpikir kritis memiliki karakter khusus yang dapat diidentifikasi dengan melihat bagaimana seseorang dalam menyikapi suatu masalah, informasi atau argumen. Ferret (dalam Abrori, 2004) dan Fowler (2004) berpendapat bahwa karakteristik pemikir kritis adalah sebagai berikut:

a. Memiliki sifat ingin tahu, mencari bukti untuk mendukung asumsi dan keyakinannya secara jujur, mampu menguji masalah, dan mampu menyesuaikan opini ketika faktafakta baru ditemukan

b. Mampu menentukan serangkaian kriteria dalam menganalisis ide, dan tertarik dalam menemukan solusi baru

c. Mampu menolak informasi yang tidak benar atau tidak relevan 
d. Memahami ketidaktepatan dari opini seseorang, probabilitas bias dalam opini tersebut dan resiko penggunaan bukti menurut pilihan personal

e. Mampu mengakui kekurangan tentang pemahaman atau informasi

f. Mendengarkan dengan cermat dan mampu memberikan umpan balik

g. Melihat berpikir kritis sebagai proses berpikir sepanjang hayat terhadap penilaian diri

h. Menunda penilaian jika belum mendapat bukti yang memadai untuk mendukung sebuah keputusan

i. Terbiasa mengajukan pertanyaan tentang pandangan seseorang dan berusaha memahami asumsi yang penting terhadap pandangan itu serta implikasi dari pandangan-pandangan itu

Masalah yang terdapat di dalam CCT ini berupa pertanyaan-pertanyaan "apakah jika, apakah yang salah, mengapa salah dan apa yang harus dilakukan untuk mengoreksi kesalahannya". Krulik \& Rudnick (1995) menyatakan bahwa pada pertanyaan "apakah jika" memungkinkan seseorang untuk memeriksa kembali masalah, dan melihat apakah pengaruh perubahan ini terhadap proses pencarian solusi atau jawabannya. Dengan cara ini analisis tentang berpikir kritis terjadi penguatan. Sedangkan dalam pertanyaan "apakah ada yang salah" peserta didik mempunyai kesempatan lain untuk menggunakan kemampuan berpikir kritis untuk menjelaskan masalah sesuai dengan jawabannya. Oleh karena itu, jawaban terdiri dari kesalahan, baik dalam konsep maupun perhitungannya. Tugas peserta didik adalah menemukan kesalahan, mengoreksi dan menjelaskan apakah yang salah, mengapa salah dan apa yang harus dilakukan untuk mengoreksi kesalahannya?.

Untuk masalah yang memuat pertanyaan "apakah jika" maka indikator berpikir kritis yang terdapat dalam Tabel 1 dapat diuraikan sebagai berikut.

a. Mengidentifikasi masalah. Indikator ini teridentifikasi ketika peserta didik mampu merumuskan masalah/tujuan dari pertanyaan membandingkan persamaan dan perbedaan..

b. Memeriksa data/informasi yang ada. Indikator ini teridentifikasi ketika peserta didik mampu: mendeteksi ketercukupan data

c. Memberikan alasan berdasarkan fakta. Indikator ini teridentifikasi ketika peserta didik mampu: memberikan alasan untuk setiap langkah penyelesaian yang dikerjakan

d. Membuat kesimpulan berdasarkan fakta yang ada. Indikator ini teridentifikasi ketika peserta didik mampu: membuat kesimpulan logis berdasarkan langkah penyelesaian yang telah dikerjakan

e. Memahami konteks permasalahan. Indikator ini teridentifikasi ketika peserta didik mampu: mengetahui informasi yang sesuai dengan permasalahan yang diajukan

f. Menjelaskan arti atau istilah yang digunakan dalam berpendapat baik secara lisan maupun tulisan. Indikator ini teridentifikasi ketika peserta didik mampu: mengetahui dan dapat menjelaskan arti atau istilah yang digunakan dalam menyelesaikan masalah

g. Meninjau kembali keputusan yang telah diambil. Indikator ini teridentifikasi ketika peserta didik mampu: memeriksa kembali setiap langkah penyelesaian yang sudah dikerjakan

Sedangkan untuk masalah yang memuat pertanyaan "apakah yang salah, mengapa salah dan apa yang harus dilakukan untuk mengoreksi kesalahannya?" maka indikator berpikir kritis yang terdapat dalam Tabel 1 dapat diuraikan sebagai berikut. 
a. Mengidentifikasi masalah. Indikator ini teridentifikasi ketika peserta didik mampu: merumuskan masalah/tujuan dari pertanyaan

b. Memeriksa data/informasi yang ada. Indikator ini teridentifikasi ketika peserta didik mampu mendeteksi ketercukupan data dan menentukan informasi yang tidak relevan

c. Memberikan alasan berdasarkan fakta yang relevan. Indikator ini teridentifikasi ketika peserta didik mampu:

- memberikan alasan untuk setiap langkah penyelesaian yang dikerjakan

- memberikan alasan mengapa informasi yang diberikan tidak relevan

d. Membuat kesimpulan berdasarkan fakta yang ada. Indikator ini teridentifikasi ketika peserta didik mampu: membuat kesimpulan logis berdasarkan langkah penyelesaian yang dilakukan untuk memperbaiki kekeliruan informasi

e. Memahami konteks permasalahan. Indikator ini teridentifikasi ketika peserta didik mampu: mengetahui informasi yang sesuai dengan permasalahan yang diajukan

f. Menjelaskan arti atau istilah yang digunakan dalam berpendapat baik secara lisan maupun tulisan. Indikator ini teridentifikasi ketika peserta didik mampu: mengetahui dan dapat menjelaskan arti atau istilah yang digunakan dalam menyelesaikan masalah

g. Meninjau kembali keputusan yang telah diambil. Indikator ini teridentifikasi ketika peserta didik mampu: memeriksa kembali setiap langkah penyelesaian yang sudah dikerjakan

Meskipun berupa kartu permainan tetapi pertanyaan-pertanyaan yang terdapat di dalam CCT adalah soal analisis sehingga di dalam menjawab pertanyaan-pertanyaan dalam media ini siswa dituntut untuk memahami konsep dari materi dengan baik. Jika siswa tidak memahami konsep dengan baik maka siswa tidak akan mengetahui langkah mana yang salah dalam CCT yang berupa stimulus jawaban. Selain itu, jika tidak memahami konsep maka siswa juga tidak akan sanggup memberikan jawaban atau langkah penyelesaian dengan baik dan benar. Berikut ini adalah contoh soal SPLTV (Sistem Persamaan Linear Tiga Variabel) yang memuat indikator berfikir kritis.

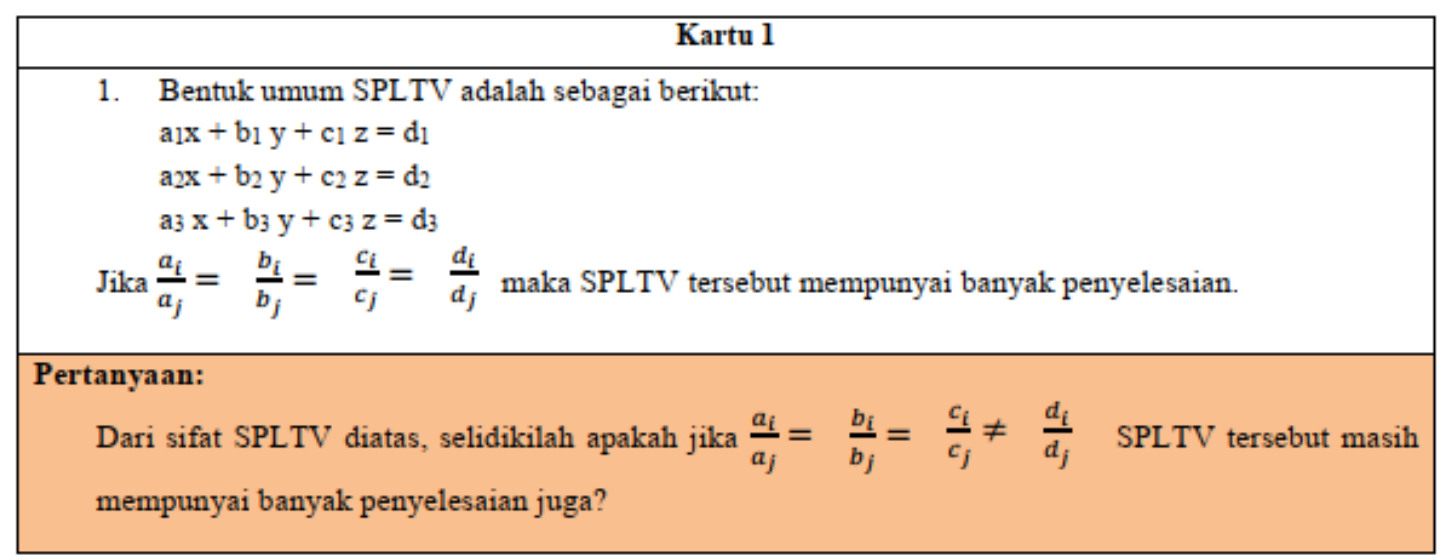

Gambar 1. Contoh kartu 1 
Pak Bambang mendapat pesanan untuk mengerjakan beberapa unit kerajinan. Rencannya pekerjaan tersebut akan dikerjakan bersama Pak Cipto dan Pak Dedi. Jika dikerjakan Pak Bambang dan Pak Cipto, pesanan akan selesai dalam waktu 6 minggu. Jika dikerjakan Pak Bambang dan Pak Dedi, pesanan akan selesai dalam waktu 8 minggu. Jika pesanan dikerjakan Pak Cipto dan Pak Dedi, pesanan akan selesai dalam waktu 4 minggu. Berapa minggu pesanan akan selesai jika dikerjakan mereka bertiga?

Penyelesaian:

Misal : $\mathrm{x}=$ waktu yang diperlukan Pak Bambang

$\mathrm{y}=$ waktu yang diperlukan Pak Cipto

$\mathrm{z}=$ waktu yang diperlukan Pak Dedi

dari soal muncul persamaan

$$
\begin{aligned}
& x+y=6 \\
& x+z=8 \\
& z+y=4
\end{aligned}
$$

dari (1) dan (2) maka:

$$
\begin{aligned}
& x+y=6 \\
& x+z=8 \\
& \hline y-z=-2
\end{aligned}
$$

$$
\text { dari (3) dan (4) maka: }
$$

$$
\mathrm{z}+\mathrm{y}=4
$$$$
\mathrm{y}-\mathrm{z}=-2
$$

$$
2 \mathrm{y}=2 \text { maka } \mathrm{y}=1
$$

untuk $y=1$ substitusi ke pers (1): dari $\mathrm{x}=5$ substitusi ke pers (2);

$$
\begin{array}{rr}
x+y=6 & \begin{array}{r}
x+z=8 \\
x+1
\end{array}=\underline{x}=5
\end{array}
$$

Maka, jika dikerjakan bersama $=5+1+3=9$ minggu

\section{Pertanyaan:}

Dari jawaban di atas, amatilah apakah ada langkah penyelesaian yang salah? Jika ada jelaskan mengapa hal itu salah? Bagaimanakah penyelesaian yang benar menurut anda?

Gambar 2. Contoh kartu 2

\section{Media CCT (Card Of Critical Thingking) dengan Pendekatan Problem Based Learning (PBL)}

Di dalam proses pembelajaran, media CCT dilaksanakan dengan pendekatan PBL. Pendekatan PBL dipilih dalam pelaksanaan CCT karena karakteristik dari pendekatan ini yang menitik beratkan pada pemberian masalah untuk mengaktifkan siswa dalam rangka mengkonstruk pengetahuan sendiri. Karakteristik lain dari PBL yang sangat menonjol adalah adanya kegiatan siswa bekerja di dalam kelompok belajar. Dengan pembentukan kelompok belajar diharapkan siswa dapat berkomunikasi, berkolaborasi, dan bertukar pendapat ataupun berbagi pemahaman (siswa yang berkemampuan tingggi dapat mengajari atau berbagi pemahaman dengan siswa yang berkemampuan rendah). Mengingat pentingnya kegiatan bekerja di dalam kelompok belajar, maka guru dituntut untuk dapat membentuk kelompok belajar yang heterogen.

Pendekatan PBL memiliki beberapa sintaks yang harus dilaksanakan secara runtut. Sintak dari PBL ini sendiri terdiri dari memberikan orientasi tentang permasalahan kepada siswa, mengorganisasikan siswa dalam belajar, membantu investigasi mandiri dan kelompok, mengembangkan dan menyajikan hasil karya, menganalisis dan mengevaluasi proses pemecahan masalah. Tabel 2 berikut ini adalah rancangan penerapan media CCT (card of critical thingking) berdasarkan kriteria berfikir kritis dengan pendekatan problem based learning (PBL): 
Tabel 2. Rancangan Penerapan CCT dengan Pendekatan PBL

\begin{tabular}{|c|l|l|}
\hline Fase & \multicolumn{1}{|c|}{ Langkah } & \multicolumn{1}{c|}{ Perilaku Siswa } \\
\hline 1 & $\begin{array}{l}\text { Memberikan orientasi } \\
\text { tentang permasalahan } \\
\text { kepada siswa }\end{array}$ & $\begin{array}{l}\text { Mendengarkan penjelasan guru tentang tujuan } \\
\text { pembelajaran, serta cara menerapkan CCT selama } \\
\text { proses pembelajaran }\end{array}$ \\
\hline 2 & $\begin{array}{l}\text { Mengorganisasikan siswa } \\
\text { dalam belajar }\end{array}$ & $\begin{array}{l}\text { Memposisikan diri dalam kelompok belajar yang } \\
\text { beranggotakan 4 orang siswa. } \\
\text { - Mengambil 2 buah kartu CCT untuk setiap } \\
\text { kelompok belajar } \\
\text { Berdiskusi dalam kelompok belajar untuk } \\
\text { menyelesaikan masalah yang diberikan }\end{array}$ \\
\hline 3 & $\begin{array}{l}\text { Membantu investigasi } \\
\text { mandiri dan kelompok }\end{array}$ & $\begin{array}{l}\text { Menganalisis CCT yang diterima dan bekerja } \\
\text { dalam kelompok belajar } \\
\text { - Menuliskan hasil analisis pada lembar jawab yang } \\
\text { diberikan oleh guru }\end{array}$ \\
\hline 4 & $\begin{array}{l}\text { Mengembangkan dan } \\
\text { menyajikan hasil karya }\end{array}$ & $\begin{array}{l}\text { Mempresentasikan hasil kerja kelompok di depan } \\
\text { kelas }\end{array}$ \\
\hline 5 & $\begin{array}{l}\text { Menganalisis dan } \\
\text { mengevaluasi proses } \\
\text { pemecahan masalah }\end{array}$ & $\begin{array}{l}\text { Dengan bantuan dari guru siswa merefleksi hasil } \\
\text { analisis terhadap sifat atau aturan dari materi yang } \\
\text { ditentukan }\end{array}$ \\
\hline
\end{tabular}

Berdasarkan Tabel 2 di atas dapat diketahui bahwa pelaksanaan CCT dengan pendekatan PBL ini dimulai dengan apersepsi dimana guru menyampaikan tujuan serta proses pembelajaran yang akan dilakukan pada hari itu. Kegiatan tersebut dilakukan untuk memastikan bahwa siswa telah siap melakukan kegiatan pembelajaran. Kegiatan pembelajaran dengan PBL kemudian dilanjutkan dengan mengorganisir siswa ke dalam kelompok belajar yang heterogen. Setelah siswa memposisikan diri, guru kemudian mempersilahkan perwakilan dari setiap kelompok untuk mengambil dua buah kartu CCT yang diletakkan di meja guru. Kartu yang dimaksud memuat dua tipe soal yaitu "apakah jika", dan "apakah yang salah, mengapa salah dan apa yang harus dilakukan untuk mengoreksi kesalahannya?". Setelah kembali ke kelompok masing-masing, maka guru memastikan bahwa setiap anggota kelompok berpartipasi aktif dalam menyelesaikan soal berfikir kritis yang terdapat dalam CCT.

Selama bekerja di dalam kelompok belajar, maka siswa menganalisis soal-soal pertanyaan CCT kemudian menuliskan jawaban atau pendapat mereka di dalam lembar jawaban. Kegiatan guru selama siswa bekerja dalam kelompok belajar adalah sebagai fasilitator agar siswa dapat menyelesaikan dan memahami soal-soal CCT dengan baik. Setelah siswa menuliskan jawaban ataupun pendapat mereka dalam lembar jawaban maka, perwakilan dari setiap kelompok mempresentasikan hasil diskusi. Jika terdapat kelompok belajar yang memiliki kartu soal yang sama dengan kelompok yang presentasi maka kelompok tersebut dapat memberikan tanggapan terhadap hasil presentasi kelompok belajar yang maju di depan. Jika semua kelompok telah mempresentasikan hasil diskusi, maka guru bersamasama dengan siswa melakukan refleksi terhadap hasil diskusi yang telah dilakukan. Pada tahap ini, guru dapat mengevaluasi hasil diskusi yang dianggap kurang ataupun membantu siswa untuk menyimpulkan sifat ataupun pemantapan terhadap konsep yang sedang dipelajari. 


\section{Kesimpulan dan Saran}

Berdasarkan uraian di atas maka dapat disimpulkan bahwa langkah-langkah penerapan CCT (Card Of Critical Thingking) Untuk dapat meningkatkan kemampuan berfikir kritis siswa adalah sebagai berikut:

a. Tahap Awal,

Pada tahap ini dilakukan dengan apersepsi dimana siswa mendengarkan dan mencatat tujuan pembelajaran yang disampaikan guru, serta mendengarkan dan merespon penjelasan guru. Kegiatan pembelajaran dengan PBL kemudian dilanjutkan dengan mengorganisir siswa ke dalam kelompok belajar yang heterogen. Setelah siswa memposisikan diri, guru kemudian menjelaskan tugas dan tanggung jawab yaitu menyelidiki secara kelompok tentang penerapan CCT

b. Tahap Inti,

Guru mempersilahkan perwakilan dari setiap kelompok untuk mengambil dua buah kartu CCT yang diletakkan di meja guru. Langkah selanjutnya, siswa bekerja dalam kelompok belajar. Selama bekerja di dalam kelompok belajar, maka siswa menganalisis soal-soal pertanyaan CCT kemudian menuliskan jawaban atau pendapat mereka di dalam lembar jawaban. Kegiatan guru selama siswa bekerja dalam kelompok belajar adalah sebagai fasilitator agar siswa dapat menyelesaikan dan memahami soal-soal CCT dengan baik.

Setelah siswa menuliskan jawaban ataupun pendapat mereka dalam lembar jawaban maka, perwakilan dari setiap kelompok mempresentasikan hasil diskusi. Jika terdapat kelompok belajar yang memiliki kartu soal yang sama dengan kelompok yang presentasi maka kelompok tersebut dapat memberikan tanggapan terhadap hasil presentasi.

c. Tahap Akhir,

Jika semua kelompok telah mempresentasikan hasil diskusi, maka guru bersama-sama dengan siswa melakukan refleksi terhadap hasil diskusi yang telah dilakukan. Pada tahap ini, guru dapat mengevaluasi hasil diskusi yang dianggap kurang ataupun membantu siswa untuk menyimpulkan konsep yang telah dipelajari.

Saran dari artikel ini adalah dilakukan penelitian lebih lanjut untuk melihat keefektifan media CCT dalam pembelajan matematika. Semoga artikel ini bisa menjadi motivasi dalam membuat media pembelajan yang dapat melatih kemampuan berfikir kritis siswa. 


\section{Daftar Pustaka}

Abrori, C. (2004). Berpikir Kritis (Critical Thinking) dalam Profesi Dokter. http://elearning.unej.ac.id.

Askury. (2007). Pengembangan Kompetensi Mahasiswa Materi Matematika Sekolah melalui Pembelajaran CRL dalam Rangka Mempersiapkan Praktek Pembelajaran di Kelas. Universitas Negeri Malang.

Brown, M. G. (2018). Education and the Fourth Industrial Revolution-Learning \{Re\}imaginedMedium. https://medium.com/learning-re-imagined/education-and-the-fourth-industrialrevolution-cd6bcd7256a3

Chao Jr, R. (2017). Educating for the fourth industrial revolution. University World News.https://www.universityworldnews.com/post.php?story=20171107123728676

Ennis, R. H. (2011). Ideal critical thinkers are disposed to: Inquiry: Critical Thinking Across the Disciplines, 26(2), 4-4. https://doi.org/10.5840/inquiryctnews201126214

Fowler, B. (2004). Critical Thunking Across the Curriculum Project. Journal Longview Community College. http://kcmetro.cc.mo.us/longv-iew/ctac/definitions.htm.

Huda, U. (2014). Peningkatan Kemampuan Berpikir Kreatif Matematis dan Habits of Thinking Independently (HTI) Siswa melalui Pendekatan Open-Ended dengan Setting Kooperatif. [Tesis]. Universitas Pendidikan Indonesia.

Huitt, W. (1998). Educational Psychology Interactive: Critical thinking. http://www.edpsycinteractive.org/topics/cognition/critthnk.html

Krulik, S., \& Rudnick, J. A. (1995). The new sourcebook for teaching reasoning and problem solving in elementary school. Allyn and Bacon.

Masek, A., \& Yamin, S. (2011). The Effect of Problem Based Learning on Critical Thinking Ability: A Theoretical and Empirical Review. 7.

Ocak, G., \& Eğmir, E. (2016). The Relationship Between Pre-Service Teachers' Critical Thinking Tendencies and Problem Solving Skills. Participatory Educational Research, spi16(2), 33-44. https://doi.org/10.17275/per.16.spi.2.4

Pusat Kurikulum. (2006). Kurikulum 2006: Standar Isi Mata Pelajaran Matematika untuk Sekolah Dasar/Madrasah Ibtidaiyah. Depdiknas.

Roh, K. H. (2003). Problem-based Learning in Mathematics. ERIC/CSMEE, 3.

Rosnani, \& Suhailah. (2003). Finishing School. Vocat.Educ, 62(5), 29-31.

Salim. (2016). Pengembangan bahan ajar matematika berbantuan software derive untuk meningkatkan kemampuan berpikir kritis matematis siswa kelas xi ipa sma negeri 1 pasarwajo. Indonesian Digital Journal of Mathematics and Education, Volume 3 Nomor 4. http://idealmathedu.p4tkmatematika.org

Scriven, M., \& Paul, R. (1987). Defining Critical Thinking. http://criticalThinking.org

Trilling, B., \& Fadel, C. (2009). 21st century skills: Learning for life in our times. Jossey-Bass, a Wiley Imprint.

Uzel, D., \& Uyangor, S. M. (2006). Attitudes of 7th class students toward mathematics in realistic mathematics education. International Mathematical Forum, 1951-1959. https://doi.org/10.12988/imf.2006.06172

Vieira, R. M., Tenreiro-Vieira, C., \& Martins, I. P. (2011). Critical thinking: Conceptual clarification and its importance in science education. Critical Thinking, 12.

Widyatiningtyas, R., Kusumah, Y. S., Sumarmo, U., \& Sabandar, J. (2015). The impact of problembased learning approach to senior high school students' mathematics critical thinking ability. Journal on Mathematics Education, 6(2), 107-116. https://doi.org/10.22342/jme.6.2.2165.107116 